\title{
Financial component of the economic security of the Arctic regions
}

\author{
Mikhail Ulchenko ${ }^{1, *}$ and Nikita Ponomarev ${ }^{2}$ \\ ${ }^{1} \mathrm{PhD}$ (Economics), Associate Professor, Leading Researcher, G. P. Luzin Institute for Economic Studies of the Kola Science Centre of \\ the RAS, 184209, Fersman st., 146, Apatity, Russia \\ ${ }^{2}$ Applicant, G. P. Luzin Institute for Economic Studies of the Kola Science Centre of the RAS, 184209, Fersman st., 146, Apatity, Russia
}

\begin{abstract}
The article is devoted to the study of issues of ensuring the economic security of the Arctic regions of the Russian Federation. It is proved that the most important element of the system of ensuring the economic security of the state and regions is the financial component. At the same time, the financial security of the economy depends not only on the amount of available financial resources, but also on the intensity of financial flows. The concept of "regional finance system" has been clarified. It is concluded that in the current unfavorable macroeconomic conditions, the cost of making management decisions aimed at creating the necessary amount of financial resources sufficient to ensure the economic security of regions and the implementation of national projects is significantly increased. It is revealed that the main instrument of financial regulation of the development of the Arctic regions is the so-called system of inter-budget transfers. At the same time, the current legislation does not distinguish the regions of the Arctic zone of the Russian Federation into a separate category, all regions can apply for subsidies from the federal budget on an equal basis.
\end{abstract}

\section{Introduction}

Since the end of the XX century, interest in the Arctic and the shelf of the Arctic seas has been constantly growing. This is due to the huge reserves of oil, natural gas, diamonds, gold, palladium, aluminum, copper, Nickel and other types of minerals that can meet the ever-growing needs of the economies of developed countries [1]. The Russian Federation, as a state with more than $17 \%$ of its territory located in the Arctic zone, also seeks to actively use this competitive advantage, constantly increasing the volume of extraction of these minerals. The development of the resources of the Russian Arctic have historically follows the path of "habitation" of these areas and accompanied by such problems as: dependency on the supply of products from regions with more favorable climatic conditions; high cost of production; remoteness from major centres of industry; the Exodus; the unsatisfactory state of most of the objects of housing and communal services. In the conditions of economic and political instability in the world, the development of Arctic resources is becoming a major task, the solution of which largely depends not only on the success of economic development, but also on ensuring Russia's national security.

\section{Theoretical foundations of economic security}

The first mention of such concepts as" economic security "and" national security" dates back to the first half of the XX century. It is in this time of economic crisis in USA which affected the economic position of some European countries was accompanied by a significant rise in unemployment, was the main reason for the appearance of the term "national economic security", which at the time meant the state of the economy of the state.

Despite the fact that in modern economic conditions these terms are also closely interrelated, the essence of their interpretations has changed somewhat. The concept of "national security" is much broader, and in addition to economic security, it includes many other types of security, such as: food, energy, military, environmental, social, and medical. The peculiarity of economic security is explained by the fact that none of the above types of security can be achieved without the necessary economic security.

\section{The financial component and its role in ensuring the economic security of the regions}

The most important element of the economic security of the state and its regions is the financial component, or as it is commonly called, the provision of financial resources. In the conditions of a market model of management, issues related to ensuring the financial independence of territorial systems are of paramount

\footnotetext{
* Corresponding author: ulchenko23@rambler.ru
} 
importance. The system of regional Finance refers to monetary relations that contribute, first, to the formation of regional financial resources, and, second, to their rational use, which ensures economic and social development. At the same time, the formation of monetary relations in territorial systems is inextricably linked with the following financial transactions:

- payment of taxes and fees by individuals and legal entities;

- constant cash flow when working with legal entities, as well as budgets of municipal districts and entities;

- with systematic replenishment of regional budgets with financial resources from the Federal budget, which are intended to ensure the economic and social development of territorial systems;

- repayment of loans that were received from the Federal budget or budgets of other regions.

The financial system of the Russian Federation subjects is not than other, as part of the national financial system, thus, when talking about her development mean not only the actual increase in financial resources, but also increase the intensity of financial flows.

Analysis of research in the field of regional Finance allows us to conclude that the most important task of financial resources is to directly support social and economic processes at the regional level, fulfill financial obligations, and cover the costs of expanded reproduction [5]. The most important elements of financial resources created at the regional level are:

- budget resources at all levels, which are used not only to Finance priority regional projects and develop the regional economy, but also to create conditions for ensuring the decent functioning of social sectors;

- grants, subventions and other revenues from higherlevel budgets, the main purpose of which is to cover the regional budget deficit;

- resources of organizations and enterprises of various forms of ownership that are used not only to Finance their own activities, but also to maintain objects that have a social purpose;

- resources of extra-budgetary funds, such as the social insurance Fund, pension Fund, compulsory medical insurance Fund;

- investments directed centrally from the Federal budget;

Thus, the financial resources of regions are understood as the resources of all institutional entities that carry out their main activities in the territory of this region.

As already noted, the financial security of the region's economy depends not only on the volume, but also on the intensity of the use of financial resources. Currently, the Russian economy is facing a number of adverse factors, such as falling oil and natural gas prices, lack of opportunities to attract significant amounts of foreign investment, and various restrictions associated with the spread of a new coronavirus infection. Such unfavorable macroeconomic conditions significantly limit the opportunities for increasing revenues to both the Federal and regional budgets. This leads to the fact that the cost of making management decisions aimed at creating the necessary amount of financial resources sufficient to ensure the economic security of the regions increases significantly.

Another factor that makes it difficult for regional authorities to meet the task of generating sufficient financial resources is that a significant part of the subjects of the Russian Federation are recipient regions. Recipient regions are regions that do not have the financial resources necessary to maintain an appropriate level of socio-economic development and that survive on funds received from the Federal budget. In such difficult conditions, ensuring the economic security of regions is possible only by improving the efficiency of regional financial management.

\section{Budget security of the regions of the Arctic zone of the Russian Federation}

At the end of 2020, the regions of the Arctic zone of the Russian Federation (the Russian Arctic), according to the presidential decree, fully or partially assigned the territory of nine regions - Arkhangelsk oblast (partially), Krasnoyarsk Krai (partially), Murmansk oblast (full), Nenets Autonomous Okrug (in full), Republic of Karelia (part of), Sakha Republic (partially), Komi Republic (in part), Chukotka Autonomous Okrug (in full), YamaloNenets Autonomous Okrug (full) $[6,7]$. The area of the designated territories is more than 9 million square kilometers, where about 2.4 million people live.

Despite the fact that these regions have significant reserves of minerals that are of strategic importance for the country's economy, the harsh natural and climatic conditions of life and remoteness significantly hinder their "habitation" and development. To solve these problems and attract qualified personnel, starting in the thirties of the twentieth century, the USSR legislated benefits for people living and working in harsh natural and climatic conditions, which contributed to the influx of population and its consolidation in the field. However, with the collapse of the Union, the opposite trend has emerged, which has not been overcome over the past 30 years.

In this situation, the issues of ensuring the budgets of the regions belonging to the Russian Arctic are of paramount importance, since without appropriate financial support, it makes no sense to talk about the development of these subjects and the implementation of national-scale projects on their territory.

Currently, the main instrument for financial regulation of the development of the Arctic regions is the so-called system of inter-budget transfers, the essence of which is that the budgets of the regions in need are additionally provided with a certain amount of financial resources. It is worth noting that the current legislation does not distinguish the Arctic regions in a separate category, all regions of the country can apply for assistance $[5,8]$. As of the end of 2019, 7 regions that are fully or partially classified as part of the Russian Arctic received such assistance. Figure 1 shows data on the amount of subsidies that were aimed at equalizing the budget provision of the regions of the Russian Arctic. 


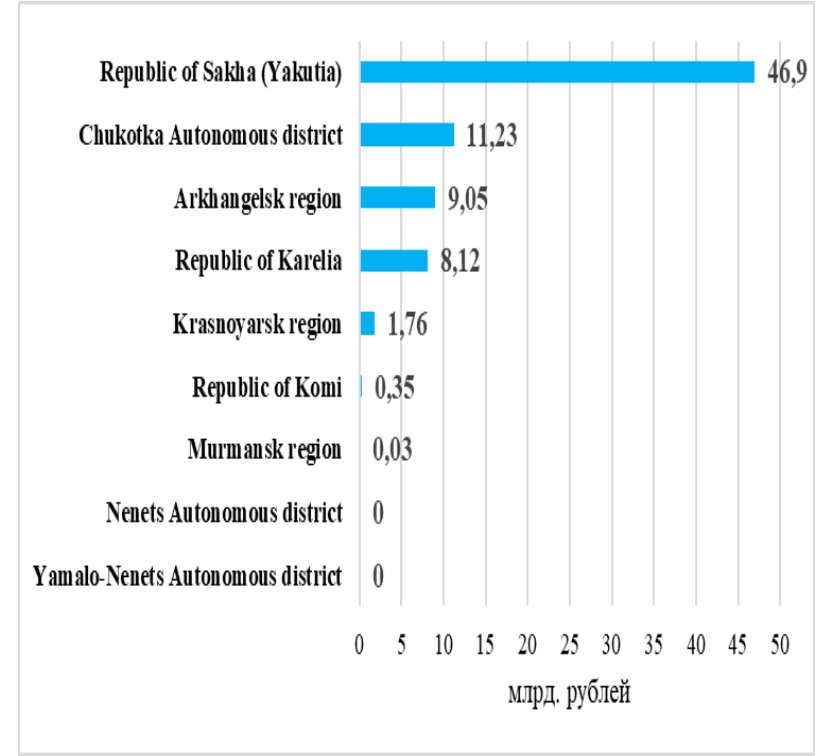

Fig.1. The volume of subsidies for equalizing budget provision to the regions of the Arctic zone of the Russian Federation in 2019, billion rubles [9]

Thus, we can conclude that the financial component is the most important element in ensuring the economic security of the Arctic regions. Thus, the fact that the regions of the Russian Arctic possess enormous reserves of hydrocarbons and other minerals of strategic importance to the economy, allows us to assert the priority of solving problems related to ensuring the Arctic territorial systems necessary financial resources that will allow to create conditions for the development of these areas and the implementation of major national projects.

The study was supported by the RFBR grant 20-01000776 A "Improvement of state financial regulation of the development of the regions of the Arctic zone of the Russian Federation as a basis for ensuring the economic security of the Russian Arctic".

\section{References}

1. S. Kozmenko and M. Ulchenko, IOP Conference Series: Earth and Environmental Science 302(1), 012123 (2019)

2. Decree of the President of the Russian Federation "On the economic security Strategy of the Russian Federation for the period up to 2030". Available online:

https://www.garant.ru/products/ipo/prime/doc/71572 608/

3. S. Glazyev, Financial business 12, 6-14 (1996)

4. L. Abalkin, Economic issues 12, 4-16 (1994)

5. E. Verbinenko and R. Badylevich, IOP Conference Series: Earth and Environmental Science, 302(1), 012140 (2019)
6. Decree of the President of the Russian Federation No. 296 of 02.05.2014 "On the land territories of the Arctic zone of the Russian Federation". Available online: http://www.kremlin.ru/acts/bank/38377 (2020)

7. Decree of the President of the Russian Federation No. 287 of 27.06.2017 "On amendments to Decree of the President of the Russian Federation No. 296 of May 2, 2014". Available online: http://www.kremlin.ru/acts/bank/42021 (2020)

8. N. Didenko, D. Skripnuk, O. Mirolyubova, V. Merkulov, V. Sevashkin, E. Samylovskaya, International Conference on Information Networking, 217-222 (2018)

9. Federal state statistics service. Available online: https://rosstat.gov.ru/databases (2020) 